\title{
Abdominal wall protrusion following herpes zoster
}

\author{
Protrusão de parede abdominal secundária a herpes zoster
}

\author{
Facundo Burgos Ruiz Junior ${ }^{1}$, Jullyanna Sabrysna Morais Shinosaki ${ }^{2}$, \\ Wilson Marques Junior ${ }^{3}$ and Marcelo Simão Ferreira ${ }^{4}$
}

\begin{abstract}
We present the case of a 62-year-old woman with abdominal segmental paresis consequent to radiculopathy caused by zoster, which was confirmed by electroneuromyography. The paresis resolved completely within three months. Recognition of this complication caused by zoster, which is easily misdiagnosed as abdominal herniation, is important for diagnosing this self-limited condition and avoiding unnecessary procedures.
\end{abstract}

Key-words: Herpes zoster. Abdominal wall protrusion. Segmental paresis. Electroneuromyography.

\section{RESUMO}

Apresenta-se caso de uma paciente de 62 anos com paresia abdominal segmentar, confirmada por eletroneuromiografia, conseqüente a uma radiculopatia devida a zoster. A paresia resolveu-se completamente em três meses. O reconhecimento desta complicação do zoster, passível de confusão com hérnia abdominal, é importante para o diagnóstico desta condição auto-limitada, sem a utilização de procedimentos desnecessários.

Palavras-chaves: Herpes zoster. Protrusão de parede abdominal. Paresia segmentar. Eletroneuromiografia.

Infection by varicella-zoster occurs as a result of reactivation of this latent neurotropic virus in the dorsal root and cranial nerve ganglia, usually decades after resolution of varicella, with higher incidence among elderly and immunocompromised patients. Although generally benign, neurological complications are common and include postherpetic neuralgia, segmental zoster paresis, encephalitis, myelitis, meningitis and cerebrovascular manifestations ${ }^{1}$. In general, the disease affects essentially sensory nerve fibers, with cutaneous rash, radicular pain and sensory changes in one or two immediately contiguous dermatomes. However, it can also induce truncal or somatic segmental motor complications, always with an intimate correlation between the dermatome and myotome affected ${ }^{26}$.

We present the case of a patient who presented a protrusion on the right flank consequent to radiculopathy caused by herpes zoster during remission from shingles.

\section{CASE REPORT}

A 62-year-old Chilean woman who was totally healthy except for well-controlled diabetes mellitus type II (with the use of oral hypoglycemic agents) was referred for neurological evaluation of an abdominal wall protrusion. Twenty-eight days earlier, the patient had noticed a painful skin rash that had not been preceded by prodromic signs. This rapidly evolved into vesicles and pustules in the area of the right T8-T10 dermatomes, and a diagnosis of herpes zoster was made. No antiviral therapy was prescribed, and the shingles were fading (Figure 1) when a bulge appeared in the patient's right flank, lateral to her rectus abdominis muscle (Figure 2). The bulge was painless and mobile, without sensorial deficit, and could be made to disappear with manual manipulation but not spontaneously, when in dorsal decubitus. There were no other complaints of abdominal symptoms (i.e. no pain, urinary retention or intestinal constipation). Abdominal examination revealed no evidence of bowel protrusion into a herniary sac and no abnormality other than the bulge. The neurological examination showed the patient to be essentially normal except for the circumscribed abdominal paresis. Electroneuromyography was performed and the nerve conduction was found to be essentially normal, apart from carpal tunnel syndrome. Needle examination showed signs of acute denervation of the external oblique muscle and no abnormalities of the rectus abdominis or T8-T10

\footnotetext{
1. Serviço de Neurologia, Hospital das Clínicas, Universidade Federal de Uberlândia, Uberlândia, MG. 2. Curso de Medicina, Faculdade de Medicina, Universidade Federal de Uberlândia, Uberlândia, MG. 3. Disciplina de Neurologia, Faculdade de Medicina de Ribeirão Preto, Universidade de São Paulo, Ribeirão Preto, SP. 4. Disciplina de Infectologia, Faculdade de Medicina, Universidade Federal de Uberlândia, Uberlândia, MG.

Address to: Dr. Facundo Burgos Ruiz Junior. Av. Marcos de Freitas Costa 105, 38400-328 Uberlândia, MG.

Telefax: 5534 3238-1456

e-mail: facundo_burgos@uol.com.br

Recebido para publicação em 27/7/2006

Aceito em 17/1/2007
} 


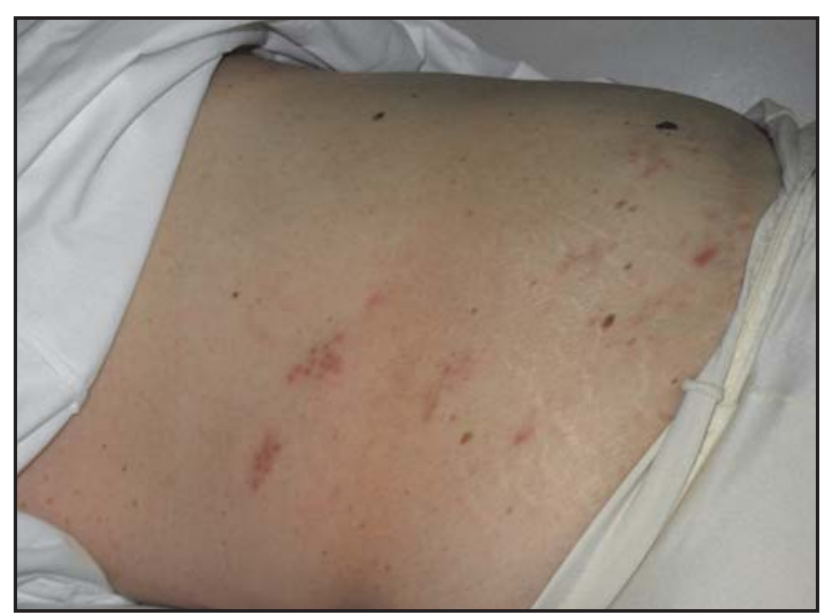

Figure 1 - Shingles in remission at the right flank.

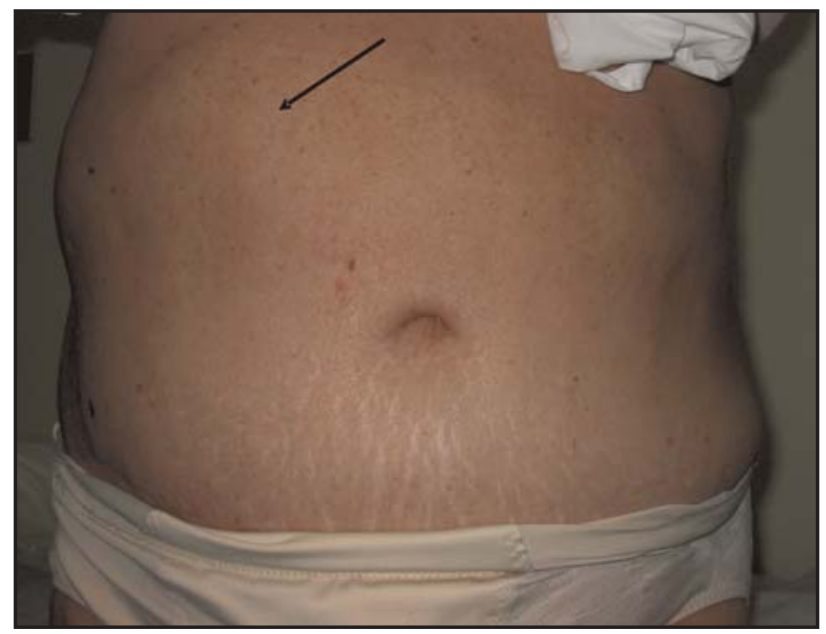

Figure 2 - Abdominal wall protrusion following berpes zoster at the right flank.

paraspinal muscles. The bulge remained stable for about 18 days, and then started spontaneous, slow and gradual remission that reached total resolution within approximately three months.

\section{DISCUSSION}

Thoracoabdominal or truncal neuropathy and lower thoracic motor radiculopathy are rare phenomena that can clinically present as abdominal wall protrusions. The differential diagnosis includes diabetes, herpes zoster, intercostal nerve lesions in surgical or other thoracic procedures, thoracic disk hernia, vertebral metastasis or trauma, clinical events with involvement of abdominal organs (appendicitis or colitis) and thoracic root alteration by another etiology 5 .

Segmental paresis is a rare postherpetic complication that is characterized by focal and asymmetrical neurogenic paresis that affects the myotome corresponding to the dermatome distribution of the rash. Its pathogenesis is still controversial, but it is presumed to consist of viral spreading from the dorsal root ganglion to the anterior horn cells, thereby resulting in medullary, root, plexus or peripheral nerve inflammation ${ }^{8}$. The incidence of clinically detectable paresis is $0.3 \%$ when the shingles appear between the T2 and L1 segments ${ }^{3}$, and there seems to be an inverse relationship between the frequency of skin lesion findings and subsequent paresis. Approximately half of the cases involve thoracic dermatomes during skin eruptions ${ }^{7}$, followed in decreasing order by the facial, cervical and lumbosacral segments. Nevertheless, the face and limbs show the highest frequencies of motor complications?

In this case, the identification of exclusive motor involvement that was temporally associated with zoster eruption with the same segmental distribution led us to a diagnosis of segmental motor paresis caused by zoster, without any procedures other than confirmatory electroneuromyography, which revealed acute denervation of the compromised area. It is of interest that, besides the segmental distribution, the bulge was restricted only to one corresponding myotome area, which also occurs in cases of truncal diabetic neuropathy ${ }^{4}$, but the temporal relationship to zoster and lack of sensory dysfunction and pain is not expected in that nosology.

As in the case presented here, all the cases of motor paresis of the thoracic roots reviewed in the literature ${ }^{379}$ also had benign evolution, with complete resolution in three months to one year. Recognition of this complication from zoster and its benign evolution is important for making a correct diagnosis, so that unnecessary complementary investigations and interventions can be avoided.

\section{REFERENCES}

1. Gilden DH, Kleinschmidt-DeMasters BK, LaGuardia JJ, Mahalingam R, Cohrs RJ. Neurologic complications of reactivation of varicella-zoster virus. New England Journal of Medicine 342:635-645, 2000.

2. Gottschau P, Trojaborg W. Abdominal muscle paralysis associated with herpes zoster. Acta Neurologica Scandinavica 84:344-347, 1991.

3. Healy C, McGreal G, Lenehan B, McDermott EW, MurphyJJ. Self-limiting abdominal wall herniation and constipation following herpes zoster infection. QJM: Monthly Journal of the Association of Physicians 91:787-789, 1998.

4. Stewart JD. Diabetic truncal neuropathy: topography of the sensory deficit. Annals of Neurology 25:233-238, 1989.

5. Stewart JD. Focal Peripheral Neuropathies, $3^{\text {rd }}$ edition. Lippincott, Williams \& Wilkins, Philadelphia, 1999.

6. Thomas JE, Howard Jr FM. Segmental zoster paresis - a disease profile. Neurology 22: 459-466, 1972.

7. Vincent KD, Davis LS. Unilateral Abdominal Distention Follow Herpes Zoster Outbreak. Archives of Dermatology 134:1168-1169, 1998.

8. Yoleri 0, Ölmez N, Öztura I, Sengul I, Gunaydin R and Memis A. Segmental Zoster Paresis of the Upper Extremity: a case report. Archives of physical medicine and rehabilitation 86:1492-1494, 2005.

9. Zuckerman R, Siegel T. Abdominal-wall pseudohernia secondary to herpes zoster. Hernia 5: 99-100, 2001. 